\title{
Use of 1-Methylcyclopropene in Ornamentals: Carnations as a Model System for Understanding Mode of Action
}

\author{
Michael S. Reid ${ }^{1}$ \\ Department of Plant Sciences, University of California, Davis, Mailstop 3, \\ 1 Shields Avenue, Davis, CA 95616 \\ Fisun G. Çelikel \\ Department of Horticulture, Faculty of Agriculture, Ondokuz Mayis University, \\ 55139 Kurupelit, Samsun, Turkey
}

Additional index words. Dianthus caryophyllus, flower senescence, petal inrolling, binding site, temperature

\begin{abstract}
The first commercial use of 1-methylcyclopropene (1-MCP) was with cut flowers and potted plants, and treatment with this compound is still the preferred strategy for protection of most ethylene-sensitive crops. Research is continuing into optimum treatment conditions and strategies for efficient application in commerce. In studies using carnation (Dianthus caryophyllus $\mathrm{L}$. 'White Sim') petals to determine the optimal conditions for commercial treatment, we noted some aspects of the inhibition response that were not consistent with the current competitive inhibition model of 1-MCP action. Our data are better explained by an alternative model in which 1-MCP binds to a site that is exposed during the allosteric changes that accompany the enzymatic activities of the binding site in the absence of ethylene.
\end{abstract}

The story of the introduction of the commercial use of 1-methylcyclopropene $(1-\mathrm{MCP})$ is tightly linked with its beneficial effects in ethylene-sensitive ornamentals (Reid and Staby, 2007). Although the use of $1-\mathrm{MCP}$ in apple storage now dwarfs its use in ornamentals, many of the strategies for commercial use were developed using ornamental models. Ornamentals provide a diversity of species and isolated petal and individual flower systems that can be used to test chemicals such as 1-MCP. Researchers have studied a range of ethylene-sensitive ornamental crops. Some wilt in response to ethylene, including orchids (Phalaenopsis), Hibiscus, stock (Matthiola incana; Celikel and Reid, 2002a) and carnation (Dianthus caryophyllus; Serek et al., 1995a, 1995b). Others respond to ethylene by abscising petals or florets, including Antirrhinum majus (Fig. 1), Alstroemeria, Penstemon, Rosa hybrida (Serek et al., 1995a), and wax flower (Chamelaucium uncinatum; Macnish et al., 2000). Potted plants studied include Begonia (Serek et al., 1995b), Kalanchoe blossfeldiana (Serek and Reid, 2000), Pelargonium peltatum (Cameron and Reid), Campanula carpatica (Sisler et al., 2004), and Lilium (Celikel et al., 2002).

Formulated as "EthylBloc," (Floralife, Walterboro, SC) dextrin-bound 1-MCP is a very effective tool for overcoming the effect of ethylene in sensitive ornamentals, both cut flowers and potted plants (Celikel et al., 2002; Serek et al., 1995a). Despite its effectiveness, $1-\mathrm{MCP}$ is not as widely used as it could be in the ornamentals industry. One major issue for

\footnotetext{
We gratefully acknowledge the financial support of the American Floral Endowment and Floralife, Inc., who also generously provided the EthylBloc. ${ }^{1}$ To whom reprint requests should be addressed; e-mailmsreid@ucdavis.edu
}

producers of ornamental crops is the gaseous nature of the compound, which leads to practical difficulties in treatment. To address the need for a convenient treatment system, Floralife, the company that commercialized $1-\mathrm{MCP}$ in North America, provides an "inthe-truck" treatment system. It comprises a bucket of water or mild alkali that is placed at the rear of the load and a water-soluble pouch containing the 1-MCP that is dropped into the bucket. The doors of the truck are closed, the bag dissolves, and sufficient 1-MCP is liberated to treat the flowers within the truck. Recently, the company has released a novel treatment system-1-MCP sachets resembling tea bags. The bags are dipped in water just before being placed within a packed box; the water diffuses through the bag, and the $1-\mathrm{MCP}$ in it is released into the air within the box. Preliminary experiments have shown this technique to be quite effective (Staby, personal communication).

Among ethylene-sensitive flowers, carnations are perhaps the most studied (Borochov and Woodson, 1989). We previously used individual petals to examine the physiology of ethylene action in carnations (Mor and Reid, 1980). Not only are carnation flowers very sensitive to ethylene, but also the kinetics of the binding site in carnations have already been determined (Sisler et al., 1986). The kilodaltons for ethylene binding in petals was estimated to be $0.1 \mu \mathrm{L} \cdot \mathrm{L}^{-1}$ and the concentration of binding sites was estimated to be $6.0 \times 10^{-9} \mathrm{~mol} \cdot \mathrm{kg}^{-1}$. Application of inhibitors $\left(\mathrm{Ag}^{+}\right.$or 2,4-norbornadiene) inhibited ethylene binding by $20 \%$ to $80 \%$.

In studies aimed at determining optimal conditions for commercial application of $1-\mathrm{MCP}$ to cut flowers and potted plants, we used carnation petals as a model ethylene response system. We noted some curious aspects of the relationship among 1-MCP, ethylene, and temperature (Celikel and Reid, 2002b). The effectiveness of 1-MCP appeared to be strongly affected by the treatment temperature and was greatly reduced by the presence of ethylene during the treatment period. Neither of these results would be predicted by the current model of 1-MCP action. We report the results of further studies using this model system and suggest an alternative model to explain the inhibitory effects of 1-MCP.

\section{MATERIALS AND METHODS}

Plant material. Untreated carnation (Dianthus caryophyllus L. 'White Sim') flowers were obtained from commercial growers or were harvested directly from the university greenhouse at standard commercial maturity (petals in the outermost whorl horizontal).

Treatment with 1-methylcyclopropene. Flowers or petals were placed in sealed chambers (20-L aquaria or 1-L mason jars) in which vigorous air circulation was provided by a small fan. The calculated weight of bound 1-MCP (EthylBloc powder, 0.14\% a.i.) required to obtain a high concentration $\left(50 \mu \mathrm{L} \cdot \mathrm{L}^{-1}\right)$ of $1-\mathrm{MCP}$ was placed in a $1-\mathrm{L}$ volumetric flask sealed with a rubber serum cap and sufficient water was injected into the flask to give an internal volume of $1 \mathrm{~L}$ and to release 1-MCP from the EthylBloc powder. Calculated volumes of the 1-MCP concentrate were removed from the flask with syringes and injected into the sealed chambers.

Measurement of the ethylene response. To quantitatively determine the extent of the ethylene response, the outer whorl of petals was removed from each of four replicate flowers, and two petals from each flower were taken to provide replicate sets of eight petals. The base of each petal was placed in a $1-\mathrm{mLl}$ glass vial, and the eight vials were placed in a small rack. The initial largest 


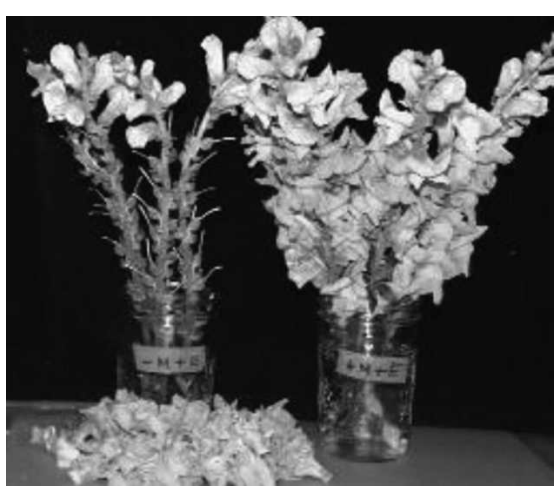

Fig. 1. Effect of 1-methylcyclopropene pretreatment $\left(0.6 \mu \mathrm{L} \cdot \mathrm{L}^{-1}, 6 \mathrm{~h}\right)$ on the response of snapdragons (Antirrhinum majus) to ethylene $\left(1 \mu \mathrm{L} \cdot \mathrm{L}^{-1}, 48 \mathrm{~h}\right)$

width of each petal was measured. The racks were placed at $20{ }^{\circ} \mathrm{C}$ for $24 \mathrm{~h}$ in a chamber ventilated with a flowing air stream $\left(40 \mathrm{~L} \cdot \mathrm{h}^{-1}\right)$ containing the desired concentration of ethylene (normally $1 \mu \mathrm{L} \cdot \mathrm{L}^{-1}$ ), the largest width of the petals was again measured, and the percent inrolling was calculated as the percent reduction in petal width. Fully inrolled petals showed an $\approx 75 \%$ reduction in diameter.

Effect temperature during 1-methylcyclopropene treatment. To determine the effect of treatment temperature on the efficacy of 1-MCP, replicate sets of carnation petals were placed in 1-L mason jars at different temperatures for $1 \mathrm{~h}$ to allow the temperature to equilibrate. The jars were then sealed and sufficient 1-MCP concentrate was injected to provide $1 \mathrm{~nL} \cdot \mathrm{L}^{-1} 1-\mathrm{MCP}$ in the jars. After $6 \mathrm{~h}$, the jars were opened and the petals aerated at the treatment temperature for $1 \mathrm{~h}$ before measurement of the ethylene response (to $1 \mu \mathrm{L} \cdot \mathrm{L}^{-1}$ ethylene, $24 \mathrm{~h}, 24{ }^{\circ} \mathrm{C}$ ).

Effect of ethylene concentration on inrolling of 1-methylcyclopropene-treated petals. To determine whether high concentrations of ethylene could overcome the effects of 1-MCP, petals were treated for $6 \mathrm{~h}$ at $24^{\circ} \mathrm{C}$ with $50 \mathrm{~nL} \cdot \mathrm{L}^{-1} 1-\mathrm{MCP}$ and then exposed at $24{ }^{\circ} \mathrm{C}$ to ethylene at concentrations from 1 to $1000 \mu \mathrm{L} \cdot \mathrm{L}^{-1}$. The inrolling of treated and air control petals was measured after $24 \mathrm{~h}$.

Effect of ethylene on the efficacy of 1-methylcyclopropene treatments. To assess the competition between 1-MCP and ethylene, petals were treated with a mixture containing $1 \mu \mathrm{L} \cdot \mathrm{L}^{-1}$ ethylene and from 15 $\min$ to $10 \mathrm{~h}$. After treatment, the petals were aerated $(1 \mathrm{~h})$ and then exposed for $24 \mathrm{~h}$ to 1 $\mu \mathrm{L} \cdot \mathrm{L}^{-1}$ ethylene (at $24^{\circ} \mathrm{C}$ ) before measurement of inrolling. Control petals were treated with $100 \mathrm{~nL} \cdot \mathrm{L}^{-1} 1-\mathrm{MCP}$ for different periods before aeration and exposure to ethylene.

\section{RESULTS}

Effect of treatment temperature. The ethylene response of carnation petals at $20{ }^{\circ} \mathrm{C}$ was completely inhibited when they had previously been treated for $6 \mathrm{~h}$ at $20^{\circ} \mathrm{C}$ with

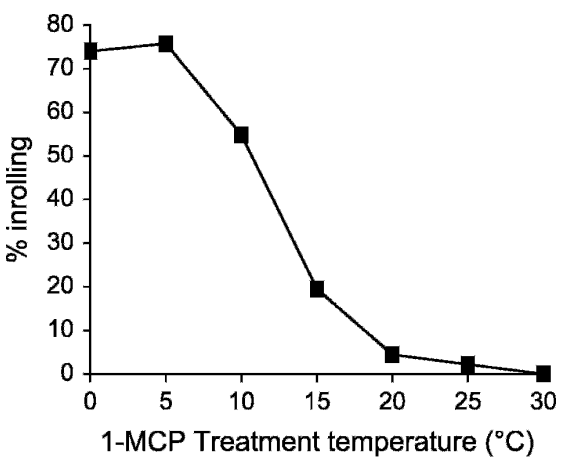

Fig. 2. Effect of treatment temperature. Carnation petals equilibrated to different temperatures were treated for $6 \mathrm{~h}$ with $1 \mathrm{~nL} \cdot \mathrm{L}^{-1} 1$-methylcyclopropene. After aeration at the treatment temperature for $1 \mathrm{~h}$, the petals were exposed to $1 \mu \mathrm{L} \cdot \mathrm{L}^{-1}$ ethylene for $24 \mathrm{~h}$ at $24{ }^{\circ} \mathrm{C}$.

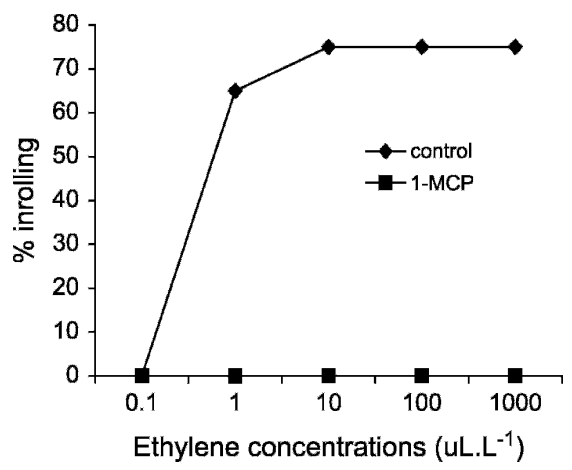

Fig. 3. Effect of ethylene concentration on the ethylene response of 1-methylcyclopropenetreated petals. Control (air) and 1-methylcyclopropene-treated $\left(50 \mathrm{~nL} \cdot \mathrm{L}^{-1}, 6 \mathrm{~h}, 24{ }^{\circ} \mathrm{C}\right)$ petals were exposed to different ethylene concentrations for $24 \mathrm{~h}$ at $24^{\circ} \mathrm{C}$.

$1 \mathrm{~nL} \cdot \mathrm{L}^{-1} 1-\mathrm{MCP}$ (Fig. 2). When the 1-MCP treatment temperate was $0{ }^{\circ} \mathrm{C}$, there was almost no inhibition of the effect of the subsequent ethylene treatment; petals lost $75 \%$ of their initial diameter indicating complete inrolling. Between these temperatures, there was a sigmoid relationship between treatment temperature and the efficacy of the 1-MCP treatment.

Effect of ethylene concentration on the ethylene response of 1-methylcyclopropenetreated petals. A 24-h treatment with 0.1 $\mu \mathrm{L} \cdot \mathrm{L}^{-1}$ ethylene had no effect on carnation petals (Fig. 3), but at $1 \mu \mathrm{L} \cdot \mathrm{L}^{-1}$, the control petals had inrolled $65 \%$ and had completely (75\%) inrolled in $10 \mu \mathrm{L} \cdot \mathrm{L}^{-1}$ ethylene. Petals previously treated for $6 \mathrm{~h}$ with $50 \mathrm{~nL} \cdot \mathrm{L}^{-1}$ 1-MCP were unaffected by subsequent ethylene exposure, even at concentrations as high as $1000 \mu \mathrm{L} \cdot \mathrm{L}^{-1}$.

Interactions between ethylene and 1methylcyclopropene. The ethylene response of petals was greatly reduced after treatment with 1-MCP for only $15 \mathrm{~min}$ and completely inhibited after $30 \mathrm{~min}$ (Fig. 4). The presence of $\mathrm{C}_{2} \mathrm{H}_{4}\left(1 \mu \mathrm{L} \cdot \mathrm{L}^{-1}\right)$ in the treatment chamber delayed the ability of $1-\mathrm{MCP}$ to inhibit ethylene action. It took $6 \mathrm{~h}$ of treatment with

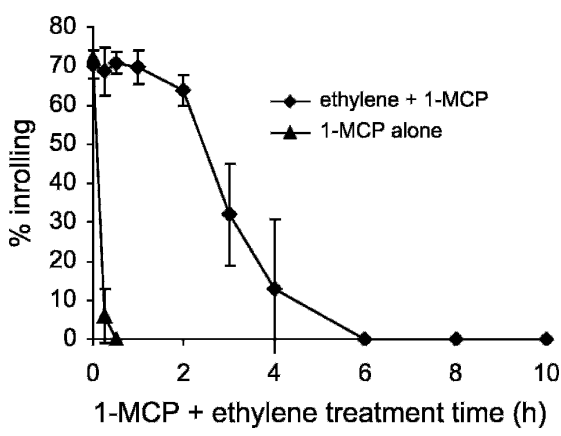

Fig. 4. Effect of 1-methylcyclopropene (1-MCP) + ethylene treatment time on response of petals to ethylene exposure. Petals were treated with 100 $\mathrm{nL} \cdot \mathrm{L}^{-1} 1-\mathrm{MCP}$ alone or with a mixture containing $1 \mu \mathrm{L} \cdot \mathrm{L}^{-1}$ ethylene and $100 \mathrm{~nL} \cdot \mathrm{L}^{-1} 1-\mathrm{MCP}$ for different periods. After aeration, the petals were then exposed for $24 \mathrm{~h}$ to $1 \mu \mathrm{L} \cdot \mathrm{L}^{-1}$ ethylene (at $24^{\circ} \mathrm{C}$ ).

the mixture of $\mathrm{C}_{2} \mathrm{H}_{4}$ and 1-MCP to achieve the inhibition achieved by a $30-$ min treatment with 1-MCP alone.

\section{DISCUSSION}

Many intriguing and commercially important questions relating to the use and action of 1-MCP remain to be resolved. These questions include determining the optimum conditions for treatment (duration, concentration, temperature) and understanding why these differ among different tissues. In particular, we do not understand the need for much higher 1-MCP concentrations to inhibit ethylene action in fruits that are producing ethylene. Nor do we have a biochemical basis for the marked differences in longevity of inhibition by 1-MCP among species and tissues nor for the variation in this property among cyclopropenes. Is this a reflection of different rates of binding site turnover or are there differential rates of dissociation of cyclopropenes from the binding site? For these and other unanswered questions about the physiology and biochemistry of this remarkable compound, ornamentals continue to provide excellent model systems. The diversity of ornamental species, their year-round availability, and relatively short lives, as well as the variation in their response to ethylene and 1-MCP makes them ideal models for biochemical and comparative studies. The carnation petal system used by Mor and Reid (1980) has proven to be particularly useful for such studies. The petals respond rapidly and strikingly to the presence of ethylene, and experiments can easily include large numbers of replicates.

Present understanding of the ethylene action cascade and the properties of the protein encoded by the putative ethylenebinding site (ETR-1) were reviewed by Stepanova and Ecker (2000). The protein is suggested to form an active dimer with six transmembrane domains (three per polypeptide), a $\mathrm{Cu}$ I ion complexed with each polypeptide, and protein kinase domains on the C-terminus, presumably functioning in 
transmission of the ethylene signal (Fig. 5). The ETR-1 protein is thought to act as a negative regulator whose normal function, presumably mediated by the C-terminal kinase, is to maintain an intermediary regulatory protein (CTR2) in an active state so that it prevents the activity of a further step in the signal cascade catalyzed by EIN-1 (Fig. 5A-B). When ethylene binds, it inhibits the kinase activity and thereby unleashes the ethylene cascade (Fig. 5C).

The inhibitory action of 1-MCP is commonly considered to be the result of compet- itive binding of $1-\mathrm{MCP}$ to the ethylenebinding site (Hall et al., 2000; Sisler et al., 1999). The data presented here suggest that this model of action is unlikely to be correct, at least for carnation petals. The fact that supersaturating concentrations of ethylene are unable to reverse the inhibition caused by 1-MCP (Fig. 3) suggests irreversible binding by $1-\mathrm{MCP}$.

One of the beauties of the carnation petal system is that responses to gaseous regulators are very rapid. In control petals (treated with 1-MCP alone), inhibition of ethylene action is complete within $15 \mathrm{~min}$ (Fig. 4). The fact that moderate concentrations of ethylene present at the time of 1-MCP treatment delay its inhibitory effects (Fig. 4) is not consistent with simple competitive binding of an agonist and highly effective inhibitor at the same binding site. Eventually (by $6 \mathrm{~h}$ ), 1-MCP does become inhibitory, even in the presence of ethylene (Fig. 4). This finding could be suggested to indicate the gradual release of ethylene from the binding site and preferential binding of $1-\mathrm{MCP}$, although this interpretation would require rather different
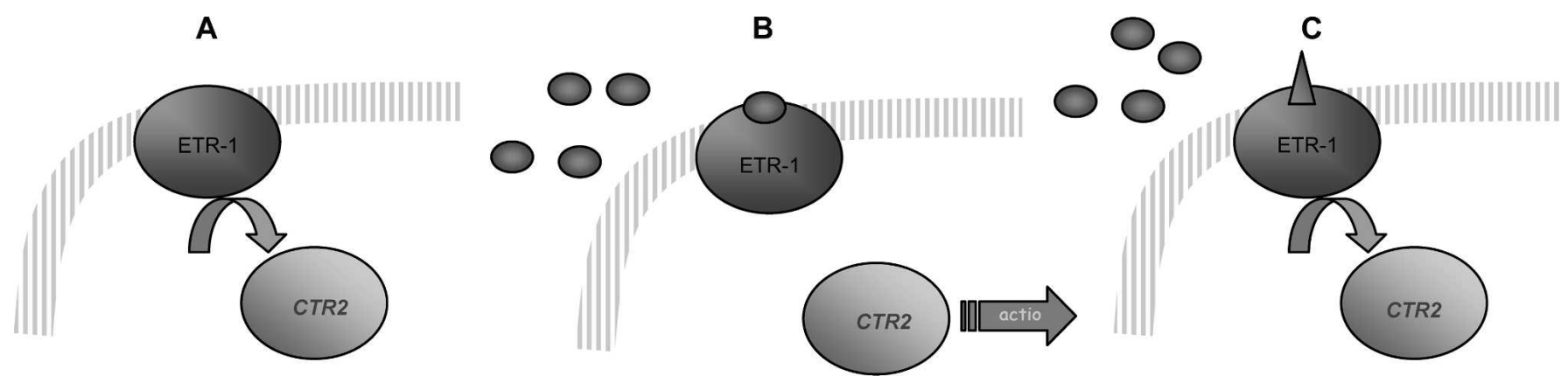

Fig. 5. Schematic of the presently accepted pathway of ethylene action and of the suggested mode of action of 1-methylcyclopropene (1-MCP). (A) In the absence of ethylene, kinase activity of the receptor (ETR-1) turns off the first step in the response cascade (CTR2). (B) When ethylene (spheres) binds, kinase activity is inhibited and the response cascade is initiated. (C) 1-MCP (cone) is assumed to bind irreversibly to the ethylene-binding domain in ETR-1, preventing ethylene binding and thereby maintaining kinase activity even in the presence of ethylene.

A

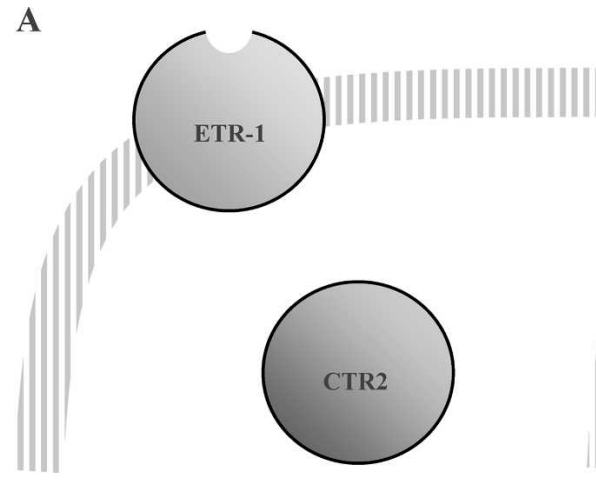

B

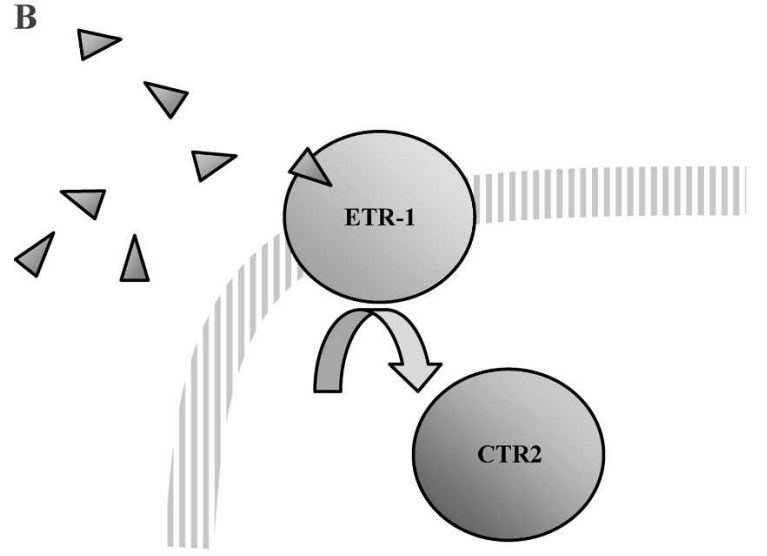

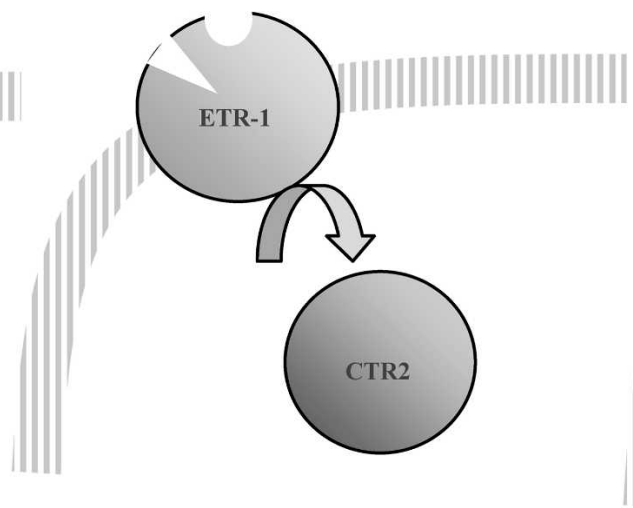

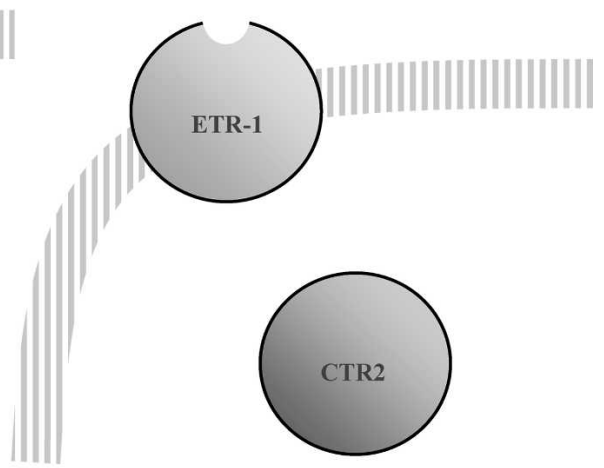

C、

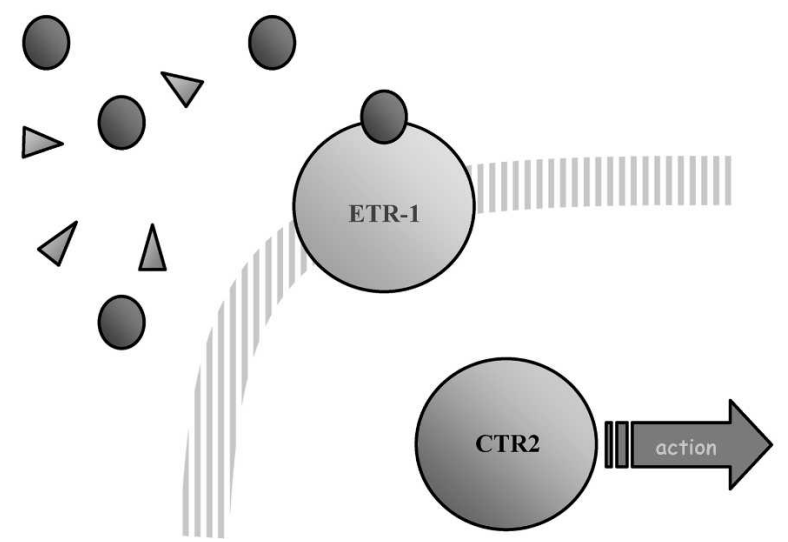

Fig. 6. Schematic of a possible alternative model for the inhibition of ethylene action by 1-methylcyclopropene (1-MCP). (A) The allosteric changes accompanying the kinase activity of the receptor (ETR-1) reveal a domain to which 1-MCP can bind. (B) When 1-MCP (cones) binds, the kinase is irreversibly turned ON and the ethylene-binding pocket is not exposed. (C) If ethylene (spheres) binds first, the kinase is turned OFF and the 1-MCP-binding pocket is therefore not exposed. 
kinetics from those found in classical competitive inhibition (in which a highly effective or irreversible inhibitor will immediately displace the agonist, and where the agonist can overcome the effects of the inhibitor if present at sufficiently high concentrations).

Likewise, the strong effect of temperature on the inhibitory activity of 1-MCP (Fig. 2) is not consistent with a direct competitive binding model, because the temperature/ inhibitor action relationship is more suggestive of the effect of temperature on enzyme activity than on a simple chemical binding. It could be argued that the temperature effect is simply an effect of temperature-induced conformational changes in the membrane-bound receptor protein, suggesting that $1-\mathrm{MCP}$ or ethylene is unable to bind at lower temperatures. However, such a conformational change might be expected to result in release of the agonists at low temperature, and inhibition by $1-\mathrm{MCP}$ is extended when treated flowers are held at low temperatures (Celikel and Reid, 2002b). It seems unlikely that the temperature effect is the result of changing diffusion kinetics (across the cuticle, for example), because inhibition at $20{ }^{\circ} \mathrm{C}$ is complete after $30 \mathrm{~min}$ and treatments in this experiment were for $6 \mathrm{~h}$.

We hypothesize that 1-MCP, rather than binding directly to the binding site, binds instead to a site that is exposed during the histidine kinase reaction that occurs when the binding site is free of ethylene (Fig. 6). The irreversible binding of 1-MCP, we postulate, would maintain the site in its "on" state, modifying the molecule so that ethylene no longer is bound to it. The present model for ethylene action suggests that when ethylene is bound to the binding site, the kinase activity is inhibited. This hypothesis explains the inability of 1-MCP to attach to the binding site in the presence of ethylene and the slow acquisition of the inhibitory effect over a period of hours (Fig. 4), because the proposed 1-MCP-binding site would not be exposed until ethylene is released from the ethylene-binding site and kinase activity resumes. It also explains the absence of any effects of $\mathrm{CO}_{2}$ on 1-MCP inhibition (Celikel and Reid, 2002b). The presence of this molecule, which is a competitive inhibitor of ethylene action (Burg and Burg, 1967), would not be expected to interfere with the effects of 1-MCP, because, in our model, the molecules bind at different sites. Certainly this hypothesis will require verification using advanced biochemical chemical and molecular tools, but it does provide an explanation for aspects of the behavior of 1-MCP that was previously very puzzling.

\section{Literature Cited}

Borochov, A. and W.R. Woodson. 1989. Physiology and biochemistry of flower petal senescence. Hort. Rev. (Amer. Soc. Hort. Sci.) 11:15-43.

Burg, S.P. and E.A. Burg. 1967. Molecular requirements for the biological activity of ethylene. Plant Physiol. 42:144-152.

Celikel, F.G., L.L. Dodge, and M.S. Reid. 2002. Efficacy of 1-MCP (1-methylcyclopropene) and promalin for extending the post-harvest life of Oriental lilies (Lilium $\times$ 'Mona Lisa' and 'Stargazer'). Sci. Hort. 93:149-155.

Celikel, F.G. and M.S. Reid. 2002a. Postharvest handling of stock (Matthiola incana). HortScience 37:144-147.

Celikel, F.G. and M.S. Reid. 2002b. An alternative model for the inhibition of ethylene action by 1-methylcyclopropene (1-MCP), p. 19-21. In: F. Mencarelli and G. Serra (eds.). Techniche postraccolta dei prodotti ortoflorofrutticoli. ARSIA, Florence, Italy.

Hall, A.E., J.L. Findell, G.E. Schaller, E.C. Sisler, and A.B. Bleecker. 2000. Ethylene perception by the ERS1 protein in Arabidopsis. Plant Physiol. 123:1449-1458.

Macnish, A.J., D.C. Joyce, P.J. Hofman, D.H. Simons, and M.S. Reid. 2000. 1-methylcyclopropene treatment efficacy in preventing ethylene perception in banana fruit and grevillea and waxflower flowers. Aust J. Exp. Agr. 40:471-481.

Mor, Y. and M.S. Reid. 1980. Isolated petals, a useful system for studying flower senescence. Acta Hort. 113:19-25.

Reid, M. and G.F. Staby. 2008. A brief history of 1-MCP. HortScience 43:83-85.

Serek, M. and M.S. Reid. 2000. Ethylene and postharvest performance of potted kalanchoe. Postharvest Biol. Technol. 18:43-48.

Serek, M., E.C. Sisler, and M.S. Reid. 1995a. Effects of 1-MCP on the vase life and ethylene response of cut flowers. Plant Growth Regulat. 16:93-97.

Serek, M., E.C. Sisler, and M.S. Reid. 1995b. 1methylcyclopropene, a novel gaseous inhibitor of ethylene action, improves the life of fruits, cut flowers and potted plants. Acta Hort. 394: 337-346.

Sisler, E.C., M.S. Reid, and S.F. Yang. 1986. Effect of antagonists of ethylene action on binding of ethylene in cut carnations. Plant Growth Regulat. 4:213-218.

Sisler, E.C., M. Serek, and E. Dupille. 2004. Comparison of cyclopropene, 1-methylcyclopropene, and 3,3-dimethylcyclopropene as ethylene antagonists in plants. Plant Growth Regulat. 18:169-174.

Sisler, E.C., M. Serek, E. Dupille, and R. Goren. 1999. Inhibition of ethylene responses by 1-methylcyclopropene and 3-methylcyclopropene. Plant Growth Regulat. 27:105-111.

Stepanova, A.N. and J.R. Ecker. 2000. Ethylene signaling: From mutants to molecules. Curr. Opin. Plant Biol. 3:353-360. 